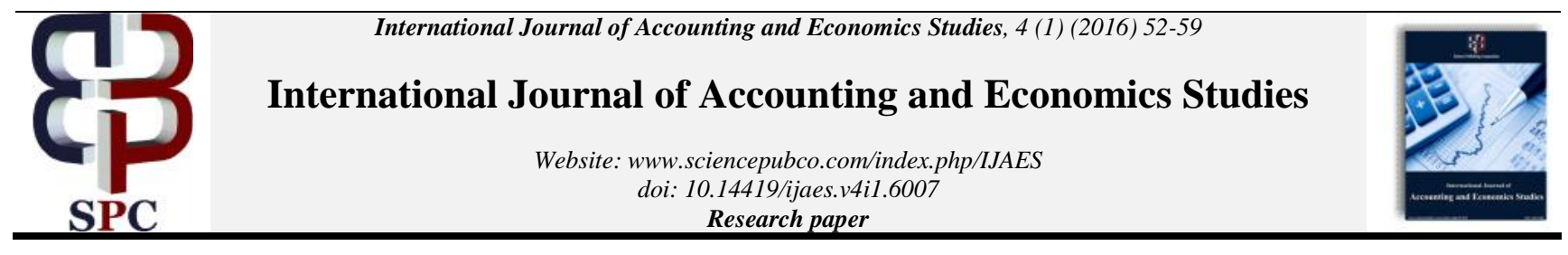

\title{
Determinants of intellectual capital disclosure in initial public offerings: case of Canadian firms
}

\author{
Hanen Ghorbel ${ }^{1 *}$, Elleuch Hela ${ }^{2}$ \\ ${ }^{1}$ Assistant professor in Accounting, Department of Accounting, High School of Business of Sfax - Tunisia \\ ${ }^{2}$ PhD student in Accounting \\ *Corresponding author_E-mail: Hanen_ghorbel@yahoo.fr
}

\begin{abstract}
The purpose of this paper is to investigate the determinants of intellectual capital information's of firms that went through IPO. Our sample includes 43 firms that IPOs listed in the Toronto Stock Exchange in 2012 of which the prospectuses for the initial public offering are available. Our study, unlike other studies focuses on the issuing prospectuses. The paper applied a disclosure index comprising of 78 items (Bukh and al (2005)) to quantify the amount of information regarding intellectual capital included in the IPO prospectuses of canadian firms. Multiple regression model and Correlation is used. The results revealed that the managerial ownership, the presence of an audit committee and industry are significantly associated with the voluntary disclosure of information about the intellectual capital in prospectuses. While firm size, age, the audit committee' activity and audit quality do not affect disclosure. The results are interpreted in the light of the increasing importance of disclosing information on intellectual capital to the capital market a in case of IPO and constitute a contribution to the ongoing debate on corporate reporting practices.
\end{abstract}

Keywords: Intellectual Capital; Disclosure, IPO; Managerial Ownership; Prospectus.

\section{Introduction}

The IPO is a significant choice for the company. It is mainly used to access the capital market, publicize the company's value, and increase its fame. However, the IPO also involves a number of constraints, such as the information costs that can become significant and the information asymmetry between the current and potential investors. The prospectus is a document intended to provide the investors with information about a new IPO, besides, it can be defined as an advertising tool containing the basic financial and non-financial information that a company makes available to potential investors when it issues securities.

The number of IPOs has sharply increased over the past few years, with a strong potential for growth. Therefore, the IPO offers a unique opportunity to study the amount and type of information to be voluntarily disclosed on the financial market, since it requires the company to report on its performance, skills, and its growth potential in a serious and reliable way in order to attract investors and generate profits and competitive returns (Bukh and al. 2005, Rimmel and al. 2009). However, the IPOs are characterized by a significant information asymmetry between the leaders of the issuing company and the potential shareholders in the way that managers have private information about the future performance of the company that the others do not have. To alleviate this asymmetry, the company's directors are required to publish voluntary information in their IPO prospectuses so that in this way, any interested party will have access to the necessary information he needs (Cazavan-Jeny \& Jeanjean, 2007).

Because of its voluntary nature, intellectual capital disclosure by IPOs is not regulated. Companies can decide both the type and the amount of intellectual capital information made public. The term "intellectual capital" collectively refers to all of the intangible resources that determine the value and competitiveness of a company. It constitutes the knowledge resources, in the form of employees, customers, processes, and technologies, which the company can mobilize in its value creation processes (Ho and al. 2012, Eirini and al. 2014).

An IPO prospectus discloses the company's financial capability, performance, operation, skills, and resources to prove its continuity and its ability to increase shareholder wealth. Mather and al. (2000) argued that management has incentives to present the company in the best position to maximize the proceeds of the share issue. Additional relevant nonfinancial information is expected to lower the cost of equity capital because an increased level of disclosure lowers the level of uncertainty of the precise valuation of the company (Botosan 1997, Verrecchia 2001). The disclosure of voluntary information such as intellectual capital is expected to reduce information asymmetry, enhance stock market liquidity, and increase demand for the company's shares Graham and al. 2005, Peterson and Plenborg 2006).

Our research aims to study its determinants for a sample of Canadian companies which are newly-introduced on the stock exchange for the year 2012.

Compared with previous studies, this study is relevant for two reasons. On the one hand, the previous studies on the disclosure determinants are scarce in the case of IPO in Canada. The conducted studies rather examine the development of the disclosure in the annual report at the time of IPO through panel work, (Harman 2013) and Canada (Ho and al. 2012) in Hong Kong. Our study, unlike other studies which refer to the annual reports, focuses on the issuing prospectuses.

The remainder of this paper is structured as follows. The literature review is discussed in section two and the hypothesis is presented 
in section three. Section four contains the methodology. Section five provides the data analysis and the empirical results. The final section is the conclusion.

\section{Littérature review}

Bukh and al. (2005) claim that the prospectuses are expected to clarify the company's financial capacity, its performance, its operations, its skills and its resources to prove a sustainable growth and the rise of the shareholders' wealth. The authors add that companies wishing to access capital markets particularly take care of the content of their prospectus and value their intangible capital publications so as to meet the investors' expectations.

Cordazzo (2007) concluded that incorporating additional information in the prospectus of the newly listed companies on the stock exchange, such as information on the intangibles, enables a better estimation of the firm's future profits.

Rimmel and al. (2009) further indicated that the prospectuses usually contain information about future expectations related to the company's development and performance, the intent and the strategic directions by comparing them with the annual reports of the same companies. In fact, these authors found that the prospectuses contain more voluntary information about the intangibles and the intellectual capital.

According to these studies, the listing prospectuses remain the document the most requested and the most used by investors wishing to participate in the capital of a newly introduced stock exchange company and by any information applicant. For their part, Deeds and al. (1997) underlined the importance of technological developments and their role in the success or failure of high-tech companies. This situation creates a special interest from investors for technological information. This interest leads the managers to use this information to signal their quality in the financial market. With reference to the signal theory, the holder of privileged information is required to follow a voluntary disclosure policy to avoid the misinterpretation risk by the external users (Verrecchia 1983). According to the agency theory (Jensen and Meckling 1976), to limit the conflicts of interest that can arise between the manager and shareholders in an IPO, the managers are incited to use their clearance mechanisms that help them reduce the information asymmetry and show the shareholders that they should respect their commitments.

On the other hand, the stakeholder theory induces the company to consider all the stakeholders' interests and ensure the protection of their interests. Information disclosure about the intellectual capital seems to be a way for the managers to meet the expectations of the different groups of stakeholders. A company which discloses more voluntary information about its intellectual capital will contribute to the reduction of the agency costs and the decrease of the information asymmetry caused by the IPO.

By referring to these three theories, it can be said that to reduce the conflicts of interest that may occur between the managers and the shareholders in an IPO, the managers are driven to use their customs clearance mechanisms which enable them to reduce the information asymmetry and prove to shareholders that they respect the contractual commitments. Therefore, voluntary information disclosure about intangible capital can be a mechanism to reduce the information asymmetry and the uncertainty of the main contractual obligations. In fact, voluntary information disclosure about intellectual capital enables the manager to show his selfdiscipline and maximize the value of the company.

\section{Hypothisis}

To put forward our hypotheses, we referred to the literature. Most studies have focused, firstly, on the variables that characterize the company, such as size, activity sector, age, and secondly, on the variables of corporate governance, such as the presence of a study board and ownership structure. For this study, we chose the variables that seem to be the most interesting in the literature.
Chavent and al. (2006), Eirini and al (2014) reported that largesized companies tend to publish more information than smaller ones. Actually, they have enough resources that help them analyze and publish understandable and detailed information. Therefore, the costs associated with an additional level of disclosure are lower for larger companies owing to a more developed reporting system. Referring to Eirini and al. (2014), size were proved to be intellectual capital disclosure determinant variable.

Rimmel and al. (2009) from a sample of the Japan Stock Exchange in 2003 , found that company size, were found to be nonsignificant factors in explaining the voluntary disclosure of information. Baccouche and al. (2010) concluded that the company's size has no significant impact on the level of voluntary information disclosure on a sample of Tunisian companies. In the French context, Kateb and al. (2009) found a positive but insignificant impact. In the same context, Cordazzo (2007) found a positive and significant impact for the newly introduced French traded companies.

Hence, our hypthesis $\mathrm{H} 1$ :

The company's size has a positive impact on the voluntary disclosure of intellectual capital information for the Canadian newly listed companies.

Cordazzo (2007), Kateb and al, (2009), Rimmel and al. (2009) showed that there is a negative relationship between the company's age and voluntary disclosure. According to these studies, younger companies disclose more information than others. They assume that young companies need to attract investors. Inversely, Baccouche and al. (2010) concluded that the company's age has a positive effect on the level of information disclosure in the Tunisian context. They concluded that older companies tend to disclose more information than others.

On the hand, Jaggi (1997) showed that the number of operating years of a company affects the accuracy of forecasts disclosed in the prospectuses of the newly listed companies.

Hence, our hypthesis $\mathrm{H} 2$ :

The company's age has a positive impact on the voluntary information disclosure of intellectual capital information for the Canadian newly listed companies.

Several studies showed that there is a positive relationship between the activity sector and information disclosure. Besides, Bukh and al. (2005) even found that the Danish high-tech companies disclose almost twice as much information as the other companies. This same result is confirmed in the work of Rimmel and al. (2009) who found that high-tech Japanese newly-listed companies disclose information on their intellectual capital more than other companies do. Kateb and al. (2009) hypothesized that French companies that belong to the high technology sector voluntarily provide more information about their intangible capital than other firms. As intellectual capital is regarded as being especially important in high-tech industries, it is anticipated that IT and biotechnology companies will disclose more information than traditional manufacturing and commercial companies.

Hence, our hypothesis H3:

The activity sector has an impact on the voluntary disclosure of intellectual capital information for Canadian newly listed companies.

Managerial ownership prior to the IPO was considered because agency problems can arise if a high proportion of shares is concentrated in the hands of majority shareholders. Kateb and al. (2009) found that the share capital held by managers negatively affects the level of the information disclosure about intellectual capital in the French case. When the share capital is low, these companies voluntarily release more information about intellectual capital than others. The same result was confirmed by $\mathrm{Li}$ and al. (2008) in the United Kingdom. On the other and, Bukh and al. (2005), concluded that there is a positive link between managerial ownership before the IPO and information disclosure about intellectual capital in the prospectus of the newly listed companies in the Danish context. Cordazzo (2007) and Sing and al. (2008) found a positive relationship between managerial ownership before the IPO and information disclosure in both the Danish and 
Italian context. The authors confirm that the information contained in the listing prospectus can reduce the information asymmetry as well as the risk associated with decision making process by investors. Bhatia and Agarwal (2015) don't found a significant relationship between managerial ownership and intellectual capital disclosure in India.

According to previous studies, this variable can affect the disclosure practices and the extent of the information disclosure in the IPO prospectus. Actually, it has an insurance mechanism for the alignment of interests between the managers and the shareholders. Hence, our hypothesis H4:

Managerial ownership is positively linked to voluntary disclosure of intellectual capital information for the Canadian newly listed companies.

The annual reports certified by one of the BIG 4 generally reflect the good condition of these companies. Therefore, when a company is audited by a BIG 4, two forms of information disclosure behavior are possible:

The first is that companies do not disclose enough information about their intellectual capital because they bear in mind the certainty that being audited by a BIG 4 , makes the investors confident in the company's financial situation. The second is an opposite behavior. The manager is motivated to disclose more information about the company's intellectual capital. He seeks to communicate the maximum amount of information to be distinguished from others. In both cases, the quality of the auditor has a positive influence in one way or another on the voluntary disclosure of information about the intellectual capital. Auditing by an known auditor during an initial public offering introduction is accompanied by a high level of information and reduces the information asymmetries.

Hence, our hypothesis H5:

The auditor's quality is assumed to have a positive impact on the voluntary disclosure of intellectual capital information in the initial public offering.

Corporate governance codes assume that the existence of an audit committee helps to reinforce the control of the company in order to limit mistakes and fraud, which in turn reduces the conflicts of interests, the information asymmetry and the accounting manipulation. Bédard and al. (2007) found that the audit committee's quality significantly reduces the degree of under-valuation of the IPO in Quebec.

By studying the English context, Jean and al. (2008) confirmed the existence of an audit committee to push companies to disclose more information about the intellectual capital. This same result was backed by Siti and al. (2011) in the Malaysian context. These authors were able to show that both the presence of an audit committee within the company and the audit committee's size are positively and significantly correlated with the voluntary disclosure of information about the intellectual capital.

By studying the extent of voluntary disclosure of information about the intellectual capital in the initial public offering in Japan, Rimmel and al. (2009) found a positive association. They assume that the audit committee is an insurance mechanism for the alignment of interests between management and shareholders

Hence, our hypothesis H6:

The existence of an audit committee within the company is positively correlated with the voluntary disclosure of intellectual capital information for the Canadian newly listed companies.

The meeting frequency of the audit committee has been the main focus of the study of Siti and al. (2011) carried in the Malaysian context. These authors assumed that there is a positive and significant relationship between the degrees of information disclosure about the intellectual capital. This hypothesis has been well confirmed. Companies with an active audit committee are assumed to have a relationship with the voluntary information on intellectual capital.

Hence, our hypothesis H7:

The meeting frequency of the company's audit committee is positively correlated with the voluntary disclosure of intellectual capital information for the Canadian newly listed companies.

\section{Research methodology}

\subsection{Sample selection}

Our sample includes all the firms that IPOs listed in the Toronto Stock Exchange in 2012 of which the prospectuses for the initial public offering are available. Actually, the final sample consists of 43 companies. Table 1 shows the distribution of the number of companies by industries. Data are collected from Toronto Stock Exchange: www.TMX.com.

The data relating to the disclosure, to the characteristics of the companies are collected from the IPO prospectuses of firm's sample. These prospectuses were drawn from the Canadian site: at www.SEDAR.com

Table 1: Sample Selection

\begin{tabular}{ccc}
\hline Industry & Number of companies & Rate (\%) \\
\hline Financial service & 18 & 41,9 \\
Real estate & 7 & 16,3 \\
Metals, minerals, oil and gas & 12 & 27,9 \\
Technology and software & 1 & 2,3 \\
Others & 5 & 11,6 \\
Total & $\mathbf{4 3}$ & $\mathbf{1 0 0 \%}$ \\
\hline
\end{tabular}

\subsection{Measures of variables and empirical model}

The level of voluntary disclosure of information about the intellectual capital is the dependent variable of our model. The company's characteristics and the governance variables are the independent ones.

To measure the extent of the intangibles disclosure in the prospectuses of the newly listed companies on the stock market, we used the disclosure index (DSI) used by Bukh and al. (2005) and Rimmel and al. (2009). The disclosure index score was constructed by examining 78 intellectual capital disclosure items grouped into six dimensions: employees, 27 items; customers, 14 items; information technology, 5 items; processes, 8 items; research and development, 9 items; and strategic statements, 15 items.

$\operatorname{DSIj}=\left(\sum_{i=1}^{\mathrm{mI}} \frac{\mathrm{d}_{\mathrm{ij}}}{\mathrm{N}}\right) \times 100 \%$, with $\mathrm{N}$ equal to the amount of total information

Dij is equal to 1 if information $\mathrm{i}$ is disclosed in the prospectus, and 0 otherwise.

$\mathrm{mj}$ is the amount of information disclosed by firm $\mathrm{j}$.

When the DSI $=0$, this means that the prospectus of the newly listed company $(j)$ contains no information about the intangibles.

The DSI variable, "information disclosure index", is the average of the above categories.

The index will be calculated in the following way:

DSIj $=\left(\sum_{i=1}^{m i} \frac{\mathbf{d}_{i j}}{\mathrm{~N}}\right) \times 100 \%$

SIZE $=$ Size of company - natural logarithm of market capitalization

AGE: The number of years between the creation of the company and its introduction on the stock market

IND $=1$, if is a financial service sector; 2 , if it is a real estate sector; 3 , if it is a sector of metals, materials, oil and gas; 4 , if it is technological and software; 5 , if it another sector.

$\mathbf{O W N}=1$, if the CEO participates in the capital before the IPO, and 0 otherwise.

BIG4 $=1$, if the auditor is a Big4 and 0 otherwise.

$\mathbf{A C}=1$, if there is an audit committee in the enterprise, and 0 otherwise.

AC-ACT $=1$ if the audit committee meets between four times or more per year and 0 otherwise.

The measures of these variables are resumed in table $n^{\circ} 2$. 
Table 2: Description and Measurements of the Variables

\begin{tabular}{|c|c|c|c|c|c|}
\hline Variables & Definitions & $\begin{array}{c}\text { Abrevia- } \\
\text { tions }\end{array}$ & \multicolumn{2}{|c|}{ Mesures } & $\begin{array}{l}\text { Expec- } \\
\text { ted } \\
\text { signs }\end{array}$ \\
\hline $\begin{array}{l}\text { Dependent } \\
\text { variable }\end{array}$ & $\begin{array}{l}\text { The index of } \\
\text { disclosure } \\
\text { about the } \\
\text { intellectual } \\
\text { capital }\end{array}$ & DIS & \multicolumn{2}{|c|}{$\operatorname{DSIj}=\left(\sum_{\mathbf{m}}^{\mathrm{m} / \mathbf{d}_{\mathbf{N}}}\right) \times 100 \%$} & \\
\hline \multirow{4}{*}{$\begin{array}{l}\text { Independ- } \\
\text { ent vari- } \\
\text { ables } \\
\text { connected } \\
\text { to the } \\
\text { govern- } \\
\text { ance } \\
\text { mecha- } \\
\text { nisms }\end{array}$} & $\begin{array}{l}\text { Share capital } \\
\text { held by the } \\
\text { manager }\end{array}$ & OWN & \multicolumn{2}{|c|}{$\begin{array}{l}1 \text { if the manager holds a } \\
\text { share capital before the } \\
\text { IPO and } 0 \text { otherwise }\end{array}$} & $+/-$ \\
\hline & $\begin{array}{l}\text { Quality of } \\
\text { external } \\
\text { auditor }\end{array}$ & BIG4 & \multicolumn{2}{|c|}{$\begin{array}{l}\text { 1: if the company is au- } \\
\text { dited by } \\
\text { a BIG4 and } 0 \text { otherwise. }\end{array}$} & $+/-$ \\
\hline & $\begin{array}{l}\text { Existence of } \\
\text { an audit } \\
\text { committee }\end{array}$ & $\mathrm{AC}$ & \multicolumn{2}{|c|}{$\begin{array}{c}1 \text { :if the company has an } \\
\text { audit committee and } \\
\text { otherwise }\end{array}$} & $+/-$ \\
\hline & $\begin{array}{l}\text { An active } \\
\text { audit com- } \\
\text { mittee }\end{array}$ & AC-ACT & \multicolumn{2}{|c|}{$\begin{array}{l}1: \text { if the number of the } \\
\text { audit committee's meet- } \\
\text { ings is superior or equal to } \\
4 \text { and } 0 \text { otherwise }\end{array}$} & $+/-$ \\
\hline \multirow{7}{*}{$\begin{array}{l}\text { Independ- } \\
\text { ent vari- } \\
\text { ables } \\
\text { related to } \\
\text { the com- } \\
\text { pany's } \\
\text { character- } \\
\text { istics }\end{array}$} & Size & SIZE & $\begin{array}{r}\text { natura } \\
\text { mark } \\
\text { express }\end{array}$ & $\begin{array}{l}\text { garithm of the } \\
\text { capitalization } \\
\text { in thousands of } \\
\text { lollars. }\end{array}$ & $+/-$ \\
\hline & Age & AGE & $\begin{array}{r}\text { Numbe } \\
\text { op }\end{array}$ & $\begin{array}{l}\text { f the company's } \\
\text { ating years }\end{array}$ & $+/-$ \\
\hline & \multirow{5}{*}{ Industries } & \multirow{5}{*}{ IND } & Value & Sector wording & \\
\hline & & & 1 & Financial service & \multirow{4}{*}{$+/-$} \\
\hline & & & 3 & $\begin{array}{l}\text { Metals, materials } \\
\text { oil and gas }\end{array}$ & \\
\hline & & & & $\begin{array}{l}\text { Technology } \\
\text { and software }\end{array}$ & \\
\hline & & & 5 & Others & \\
\hline
\end{tabular}

The empirical model is as follows:

$D S I_{i}=\beta_{0}+\beta_{1} \boldsymbol{S I Z E}_{i}+\beta_{2} \boldsymbol{A} \boldsymbol{G} \boldsymbol{E}_{i}+\beta_{3} \boldsymbol{I N D _ { i }}+\beta_{4} \boldsymbol{O W N} \boldsymbol{N}_{i}+\beta_{5} \boldsymbol{B I G}$ ${ }_{i}+\beta_{6} A C_{i}+\beta_{7} A C-A C T_{i}+\varepsilon_{i}$

\section{Empirical results}

\subsection{Descriptive statistics}

The following table makes us conclude that the level of voluntary information disclosure about the intellectual capital which exists in the IPO prospectus is moderate. This maximum rate is equal to $50.4 \%$. In addition, half of the listed companies in the Toronto Stock Exchange in 2012 had an overall rate of disclosure below $14.5 \%$.

Table 3: Descriptive Statistics of the Disclosure Rate (Global Index)

\begin{tabular}{ccc}
\hline \% of DSI & Frequency $(\boldsymbol{\%})$ & Cumulative frequency $(\boldsymbol{\%})$ \\
\hline 0,023 & 2,3 & 2,3 \\
0,044 & 2,3 & 9,3 \\
0,088 & 2,3 & 20,9 \\
0,102 & 2,3 & 30,2 \\
0,122 & 2,3 & 39,5 \\
0,145 & 2,3 & 51,2 \\
0,212 & 2,3 & 60,5 \\
0,256 & 2,3 & 67,4 \\
0,288 & 4,7 & 79,1 \\
0,426 & 2,3 & 90,7 \\
0,504 & 2,3 & $\mathbf{1 0 0 , 0}$ \\
\hline Total & $* * *$ & \\
\hline
\end{tabular}

5.2. Analysis of the correlations between the dependent variable and independent variables

Table 4 shows the Pearson's correlation test between the dependent variable of the voluntary information disclosure about the intellectual capital and the six independent variables of the model. Table 4 shows that the disclosure index score is highly positively correlated with Managerial ownership and the audit committee activity.

Table 4: Correlations

\begin{tabular}{ccccccc}
\hline DSI & SIZE & AGE & OWN & BIG4 & $\begin{array}{c}\text { AC- } \\
\text { ACT }\end{array}$ & AC \\
\hline $\begin{array}{l}\text { Correlation } \\
\begin{array}{l}\text { Significati- } \\
\text { vity }\end{array}\end{array}$ & $-0,232$ & 0,252 & 0,678 & $-0,011$ & 0,610 & 0.450 \\
\hline
\end{tabular}

*Significant correlation at 0.05 .

** Significant correlation at 0.01

\subsection{Multicoliniarity}

To carry out the multi-varied analysis, it is worth conducting two statistical tests: an autocorrelation test through the Durbin Watson test and a multicolinearity test between the explanatory variables carried out by calculating the Pearson correlation coefficient and the variance inflation factor (VIF). The Durbin-Watson value is 0.8; the threshold set by Kennedy (1985) from which we are usually exposed to serious multi-collinearity problems. These results lead us to conclude that there are no multi-collinearity problems.

Table 5: Correlation between the Explanatory Variables

\begin{tabular}{lccccccc}
\hline & SIZE & AGE & OWN & BIG4 & AC-ACT & AC \\
\hline SIZE & 1 & $-0,079$ & $-0,413^{* *}$ & $0,362^{*}$ & $-0,349^{*}$ & $-0,140$ \\
& & 0,0616 & 0,006 & 0,017 & 0,022 & 0,370 \\
AGE & & 1 & 0,241 & $-0,160$ & $-0,050$ & 0,015 \\
& & & 0,120 & 0,304 & 0,749 & 0,926 \\
OWN & & & 1 & $-0,055$ & $0,597^{* *}$ & $0,392^{* *}$ \\
& & & & 0,724 & 0,000 & 0,009 \\
BIG4 & & & & 1 & 0,016 & 0,0141 \\
& & & & & 0,919 & 0,366 \\
AC-ACT & & & & & 1 & $0,487^{* *}$ \\
& & & & & & 0,001 \\
AC & & & & & & \\
\hline
\end{tabular}

*Significant correlation at 0.05 .

** Significant correlation at 0.01

\subsection{Multivariate analysis}

However, due its nominal qualitative nature, the IND variable will deleted while keeping the other six variables. Therefore, the equation will be:

$D S I_{i}=\beta_{0}+\beta_{1} S I Z E_{i}+\beta_{2} A G E_{i}+\beta_{4} O W N_{i}+\beta_{5}$ BIG $_{i}+\beta_{6} A C_{i}$ $+\beta_{7} \boldsymbol{A C}-\boldsymbol{A C T} \boldsymbol{T}_{i}+\varepsilon_{i}$

Table 6: The Results of the Multiple Linear Regression

\begin{tabular}{|c|c|c|c|c|c|}
\hline $\begin{array}{l}\text { Dependent } \\
\text { variable }\end{array}$ & $\begin{array}{l}\text { Independent } \\
\text { variables }\end{array}$ & Coefficients & $\mathbf{T}$ & Signification & VIF \\
\hline \multirow{7}{*}{ DSI } & (Constant) & 0,074 & 1,075 & 0,289 & \\
\hline & SIZE & 0,011 & 0,768 & 0,448 & 1,448 \\
\hline & AGE & 0,002 & 1,444 & 0,157 & 1,158 \\
\hline & OWN & 0,134 & 2,810 & $0,008 * *$ & 1,924 \\
\hline & BIG4 & $-0,008$ & $-0,175$ & 0,862 & 1,237 \\
\hline & AC & 0,097 & 2,226 & $0,032 *$ & 1,908 \\
\hline & AC-ACT & 0,062 & 1,053 & 0,299 & 1,378 \\
\hline \multicolumn{2}{|c|}{$\mathbf{N}$} & \multicolumn{4}{|c|}{43} \\
\hline \multicolumn{2}{|c|}{$\mathbf{R}^{2}$} & \multicolumn{4}{|c|}{0.572} \\
\hline \multicolumn{2}{|c|}{ Adjusted $\mathbf{R}^{2}$} & \multicolumn{4}{|c|}{0.501} \\
\hline \multicolumn{2}{|c|}{$\mathbf{F}$} & \multicolumn{4}{|c|}{8.034} \\
\hline \multicolumn{2}{|c|}{ Signification } & \multicolumn{4}{|c|}{0,000} \\
\hline \multicolumn{2}{|c|}{ Durbin-Watson stat } & \multicolumn{4}{|c|}{1.817} \\
\hline
\end{tabular}

*Significant correlation at 0.05 .

$* *$ Significant correlation at 0.0 
By referring to table 6 , it can be seen that the model has a fairly satisfactory explanatory power of the order of $57.2 \%\left(\mathrm{R}^{2}=0.572\right)$. The calculated value of the Fisher's statistics, which is of the order of 8.034, The capital market appears to value the voluntary disclosure of intellectual capital informations in IPO prospectuses.

The regression results indicate that the managerial ownership before the IPO affects the information disclosure indicator about the intellectual capital. Managerial ownership before the IPO helps promote voluntary intellectual capital information disclosure for Canadian companies. This result matches those of Bukh and al. (2005), Cordazzo (2007), Singh and al. (2008), Jean and al. (2008) and Kateb and al. (2009), the managers might have a greater incentive to market their companies, and to increase their personal profit as a result of a lowered cost of capital. Thus, companies, managers disclose more information about the intellectual capital, which helps them give a better overview of the resource basis and the intellectual capital potential before the IPO. Therefore, an important information disclosure at the moment of the IPO reflects transparency and strengthens the investors' confidence in this IPO. Table 6, show a positive significate correlation between the existence of an audit committee and the level of information disclosure about the intellectual capital in the case of an IPO. This result is confirmed by studies by Ho and Wong (2001), Jean and al. (2008) and Siti and al. (2011) in the Hong Kong, English and Malaysian context. The company wishing to go public and having an audit committee shall strengthen the control to limit the mistakes and fraud so as to reduce conflicts of interest, the information asymmetry, and the accounting manipulation by the managers.

The activity sector variable is a qualitative variable that will not be considered in the regression stage. It will be handled separately by the contingency method. Therefore, this variable will be taken into account neither in the statistical tests nor in the correlation analyzes and the regression estimation.

Table7: The Company Classification on the Basis of the Disclosure Rate

\begin{tabular}{|c|c|c|c|c|}
\hline DSI_supp & Classification & Effectif & $\begin{array}{c}\text { Frequency } \\
(\%)\end{array}$ & $\begin{array}{c}\text { Cumulative } \\
\text { frequency } \\
(\%)\end{array}$ \\
\hline 1 & $\begin{array}{c}\text { DSI is lower } \\
\text { than } 20 \%\end{array}$ & 23 & 53,5 & 53,5 \\
\hline 2 & $\begin{array}{c}\text { DSI between } \\
20 \% \text { and } \\
40 \%\end{array}$ & 15 & 34,9 & 88,4 \\
\hline$<3$ & $\begin{array}{c}\text { DSI is above } \\
40 \%\end{array}$ & 5 & 11,6 & 100,0 \\
\hline Total & & 43 & 100,0 & \\
\hline
\end{tabular}

Table 8: Contingency between Supp-DSI and IND

\begin{tabular}{ccccccc}
\hline \multirow{2}{*}{ DSI_supp } & 1 & 2 & 3 & 4 & 5 & Marginal DSI_supp \\
\hline $\mathbf{1}$ & 13 & 4 & 5 & 1 & 0 & 23 \\
$\mathbf{2}$ & 5 & 3 & 6 & 0 & 1 & 15 \\
$\mathbf{3}$ & 0 & 0 & 1 & 0 & 4 & 5 \\
Marginal IND & 18 & 7 & 12 & 1 & 5 & 43 \\
\hline
\end{tabular}

The appropriate test which helps find out whether there is a possible relationship between these two variables is the Chi-square. The calculated value of chi-square is of the order of 29.68 with a null probability. As a consequence, the null hypothesis of the independence between the supp-MIS and IND characters will be rejected. It is clear that the level of information disclosure is closely linked to the activity sector. Box $(1 ; 1)$, which shows the number of financial sector companies which have a weak MIS (less than 0.20 ), is observed in the contingency table. This box has the value 13 , which is remarkably higher than others. This explains discrimination of the DSI values per activity sector.

The results in Tables 7 and 8 enable us to confirm that the activity sector has an impact on the voluntary disclosure of information about the intellectual capital during a newly Canadian IPO. This seems to be consistent with the studies of Bukh and al. (2005), Striukova and al. (2008), Rimmel and al. (2009), Kateb and al. (2009), Bhatia and Agarwal (2015), which revealed a significant effect of industries on intellectual capital information. These results concluded that high-tech industries, information technology and biotechnology disclose even twice as much information as the commercial companies or those belonging to the traditional sec- tors about the intellectual capital. However, this result could not be confirmed by Baccouche and al. (2010), in the Tunisian context, and by Branco and al. (2010) in the Portuguese context. This can be explained by the company structure in these two contexts which are poor in high-tech industries.

The results show that the company's size has no effect on the information disclosure rates about intellectual capital for our sample firms. The result is consistent with the studies of Kateb and al. (2009) and Huang and al. (2010), who found no significant correlation between the information disclosure and the company's size in the French, Malaysian and in Japan context. This can be explained by the fact that during a new IPO, companies are driven to disclose information whatever their size. Cordazzo (2007) concluded that additional information incorporation in the prospectus of the newly listed companies on the stock exchange, such as information on the intangibles, enables a better estimate of the firm's future profits of and a reduction of the information asymmetry generated by the IPO.

The company's age has no significant impact on voluntary information disclosure about intellectual capital for the newly listed companies on the Toronto Stock Exchange. This result confirm those of Bukh and al. (2005), Cordazzo (2007) in both the Italian and Danish context during a new IPO. However, Kateb and al. (2009) found a negative impact of the company's age on the information disclosure practices. Rimmel and al. (2009) found the same results the case of a newly Japanese IPO.

Therefore, the company's age is a variable that could affect the information disclosure in different ways depending on the context and nature of the business during an IPO.

The hypothesis related to the auditor's quality is rejected. This result can be explained by the fact that the auditor's quality is no longer the most important factor that attracts the investors during a new IPO. In fact, people no longer trust large audit firms after the Enron scandal, although this company was audited by the large firm "Arthur Andersen", and the bankruptcy of several multinational companies that were audited by these firms. However, be audited by a Big4 does not reduce the problems of the company's financial risk. This justifies the existence of a direct relationship, either positive or negative, between the external auditor's quality of the company and its level of voluntary disclosure of information about the intellectual capital during an IPO in Canada.

The results show that the audit committee's activity has no impact on the voluntary information disclosure about the intellectual capital during an IPO. This result is contradictory with the study of Jean and al. (2008) in the English context of the United Kingdom and Siti and al. (2011) in the Malaysian context. These studies found a positive relationship between the annual number of meetings of the audit committee and the level of voluntary disclosure of information about the intellectual capital. So, there are no conclusive results of the effect of audit committee on intellectual capital disclosure for our sample.

\section{Conclusion and discussion}

The primary objective of this study was to investigate the effect of firm's companies characteristics on voluntary disclosure of intellectual capital information in the prospectus of an IPO for a sample of firms listed on the Toronto Stock Exchange in 2012.

Our results show that there is a positive correlation between the activity sector and the voluntary disclosure of information about the intellectual capital during an IPO. Based on these results, it can be concluded that high-tech, information technology and biotechnology sectors in Canada disclose twice as much information about the intellectual capital as the trading companies or those belonging to the traditional sector. This seems to be consistent with the work of Striukova and al. (2008) in the English context, Rimmel and al. (2009) in the Japanese context, Kateb and al. (2009) in the French context and Bhatia and Agarwal (2015) in Indian context. 
These results also revealed that there is a correlation between the voluntary disclosure of intellectual capital information and the managerial ownership. This result matches those of Bukh and al. (2005), Cordazzo (2007), Singh and al. (2008), Jean and al. (2008), and Kateb and al. (2009). Indeed, the holding of a high percentage ownership of capital by managers before the initial public offering is a signal that can provide the investors with a better overview of the resource base and the potential of intellectual capital. The fact that the managers have a high share of the company's capital before the initial public offering reflects transparency and strengthens the investors' confidence in this IPO This represents an insurance mechanism for the alignment of the managers and shareholders' interests as it was stated by Hossain and al. (1994) for the listed Malaysian companies.

The results show that the presence of an audit committee within the company as well as the audit committee's size are positively and significantly associated with the voluntary disclosure of information about the intellectual capital in Canadian context for 2012 , although only $30 \%$ of companies that an audit committee The existence of an audit committee in the company have a positive effect on voluntary disclosure, respectively in the Hong Kong, the English and the Malaysian context (Ho and Wong (2001), Jean and al. (2008) and Siti and al. (2011)). This result can be explained by the fact that the objective of the company having an audit committee is the strengthening of the control, the minimization of fraud, the reduction of the conflicts of interest and the information asymmetry as well as the reduction of accounting manipulation. This can have the effect of attracting potential investors.

The company's size and age as well as the audit quality are not considered to be a determinant of the voluntary disclosure of information about the intellectual capital for the Canadian newly listed companies in 2012. Many previous studies confirm these results such as those of Bukh and al. (2005), in the Danish context, Kateb and al. (2009) in the French context, Rimmel and al. (2009) for the Japanese companies, Huang and al. (2010) and Siti and al. (2011) in the Malaysian context and Bhatia and Agarwal (2015) in Indian context.

In fact, these variables have no impact on the information disclosure about the intellectual capital during an IPO. Whatever the company's size, age and audit quality, the voluntary disclosure of information about the intellectual capital can be a company's commitment to respond to one or more actors who need information, particularly, during an IPO. Voluntary disclosure of information has to meet the requirements of information of all partners of the company and thus respond to the different pressures exerted by these, to satisfy their interests in information, to influence their perceptions and finally to reduce information asymmetry that can prevail when IPO between the leaders of the issuing company and potential shareholders.

The audit committee's activity is not a determinant of the voluntary disclosure of information about the intellectual capital for the Canadian newly listed compagnies. This result is not conclusive. In fact, among the $30 \%$ of the companies which have an audit committee, only $9.3 \%$ released information about the number of audit committee's meetings for our sample. This result seems to contradict the study of Jean and al. (2008) in the English context and the study of Siti and al. (2011) in the Malaysian context.

Finally, it can be said that activity sector, the manager's participation in the capital and the existence of an audit committee in the company have a significant impact on the voluntary disclosure of information about the intellectual capital for the Canadian newly listed companies.

By comparing the Canadian context with others, such as the Danish context studied by Bukh and al., (2005), the Italian context which was the focus of Cordazzo (2007) or even the Japanese context studied by Rimmel and al. (2009), Bhatia and Agarwal (2015) in Indian context, it appears that our results have been confirmed. In fact, during an IPO, the investors are interested in information about the company's intellectual capital in which they wish to participate. In the introduction prospectus, companies belonging to the sectors of high tech, biotechnology and information technology disclose more information about their intellectual capital than the trading companies or the companies belonging to the traditional sectors regardless of the context.

We conclude that, this study can have practical implications. In fact, since information on intellectual capital is already disclosed in IPO prospectuses this reporting form can be used as inspiration when an intellectual capital report is developed. The results also indicate that companies and their advisers believe that this type of information is important in the capital market's assessment of the company's value.

As any research task, our study has some limitations. First, our sample is limited to only 43 companies due to non-availability of all prospectuses of the Toronto newly listed companies in 2012. Moreover, this study uses data about only one period (2012). Hence, a prospective study over a longer period might better confirm the results found through time.

\section{Appendixes}

Appendix 1: The Disclosure Index (Bukh and al (2005))

\begin{tabular}{cc}
\hline ITEMS & Number \\
\hline Epmloyees & 27 \\
Customers & 14 \\
IT & 5 \\
Process & 8 \\
Research and development & 9 \\
Strategic statements & 15 \\
\hline
\end{tabular}

The informations are ranked into 6 categories as follows:

\begin{tabular}{cl}
\hline ITEMS & \multicolumn{1}{c}{ Employees (27 items) } \\
\hline 1 & Staff breakdown by age \\
2 & Staff breakdown by seniority \\
3 & Staff breakdown by gender \\
4 & Staff breakdown by nationality \\
5 & Staff breakdown by department \\
6 & Staff breakdown by job function \\
7 & Staff breakdown by level of education \\
8 & Rate of staff turnover \\
9 & Comments on changes in number of employees \\
10 & Staff health and safety \\
11 & Absence \\
12 & Staff interview \\
13 & Statements of policy on competence development \\
14 & Description of competence development program and activities \\
15 & Education and training expenses \\
16 & Education and training expenses/number of employees \\
17 & Employee expenses/number of employees \\
18 & Recruitment policies \\
19 & HRM department, division or function \\
20 & Job rotation opportunities \\
21 & Career opportunities \\
22 & Remuneration and incentive systems \\
23 & Pensions \\
24 & Insurance policies \\
25 & Statements of dependence on key personnel \\
26 & Revenues/employee \\
27 & Value added/employee \\
& Customers (14 items) \\
28 & Number of customers \\
29 & Sales breakdown by customer \\
30 & Annual sales per segment or product \\
31 & Average customer size \\
32 & Dependence on key customers \\
33 & Description of customer involvement \\
34 & Description of customer relations \\
35 & Education/training of customers \\
36 & Customers/employees \\
37 & Value added per customer or segment \\
38 & Market share (\%) \\
39 & Relative market share \\
40 & Market share, breakdown by country/segment/product \\
41 & Repurchase \\
& IT (five items) \\
42 & Description and reason for investments in IT \\
\hline &
\end{tabular}




\section{3}

Description of IT facilities

IT expenses

Processes (eight items)

Information and communication within the company

Efforts related to the working environment

Working from home

Internal sharing of knowledge and information

External sharing of knowledge and information

Measure of internal or external failures

Fringe benefits and company social programs

Environmental approvals and statements/policies

Research and development (nine items)

Statements of policy, strategy and/or objectives of R\&D activities

$\mathrm{R} \& \mathrm{D}$ expenses

R\&D expenses/sales

$\mathrm{R} \& \mathrm{D}$ invested in basic research

R\&D invested in product design/development

Future prospects regarding $R \& D$

Details of company patents

Number of patents and licenses etc.

Patents pending

Strategic statements (15 items)

Description of new production technology

Statements of corporate quality performance

Strategic alliances

Objectives and reason for strategic alliances

Comments on the effects of the strategic alliances

Description of the network of suppliers and distributors

Statements of image and brand

Corporate culture statements

Best practice

Organizational structure

Utilisation of energy, raw materials and other input goods

Investment in the environment

Description of community involvement

Information on corporate social responsibility and objective

Description of employee contracts/contractual issues

\section{Appendix 2: Information coding method}

\section{- Information about the employees:}

This first category, which deals with the employee information, contains a total of 72 pieces of information. Such information takes value 1 if the information exists in the prospectus of the involved enterprise and 0 otherwise. The average value generated from such information is the disclosure rates about the employees. This rate will be designated by 'Employee'.

\section{- Information about the customers}

The second category includes 14 pieces of information about the company's customers which are contained in its prospectus. Such information takes value 1 if the information exists in the prospectus and 0 otherwise. Average generated from such information is the information disclosure regarding the customers. This rate is designated by 'Customer'.

\section{- Information about information technology}

The third category of the information grid includes 5 pieces about the use of the technological tools and the information technologies within the company. The value 1 is assigned if there is information in the prospectus and 0 otherwise. The average value generated from such information is the rate of the information disclosure regarding the information technology. This rate is designated by 'Technology'.

\section{- Information about the processes}

The fourth group, which contains 8 pieces of information, deal with a key element within the company, namely the process. This category takes the value 1 if the information exists and 0 otherwise. The average value generated is the information disclosure about the process. This rate is designated by 'Process'

\section{- Information about research and development:}

This category is composed of 9 pieces of information about the different mechanisms of using research and development tools within the company. This category takes the value 1 if the infor- mation exists and 0 otherwise. The average value generated from these variables is the dissemination of information concerning the exploitation of the R\&D. This rate is designated by "Research"

\section{- Information about the strategic statements:}

This last category includes 15 pieces of information about the strategic statements of the company. The codification related to these items takes the value 1 if information exists and 0 otherwise. The average value of such information represents the information disclosure rates regarding the various policy statements. This rate is referred to as the 'Declaration' variable.

\section{References}

[1] Bédard, J., Coulombe, D. and Suzanne M. P. (2007). Tax Incentives on Equity and Firms' Cost of Capital: Evidence from the Quebec Stock Savings Plan. Contemporary Accounting Research, Vol. 24, No. 3, 795-824. http://dx.doi.org/10.1506/car.24.3.5.

[2] Bhatia M, \& Agarwal B, (2015). Intellectual Capital Disclosures in IPO Prospectuses of Indian Companies. International Journal of Social Sciences and Management, Vol 2, 40-51. http://dx.doi.org/10.3126/ijssm.v2i1.11685.

[3] Botosan, C.A. (1997). Disclosure level and the cost of equity capital. The Accounting Review, Vol. 72 No. 3, 323-49.

[4] Branco, M.C., Delgado, C., Sá, M. and Sousa, C. (2010). An analysis of intellectual capital disclosure by Portuguese companies. EuroMed Journal of Business, Vol. 5, No. 3, 258-278. http://dx.doi.org/10.1108/14502191011080809.

[5] Bukh, P.N., Nielsen, C., Gormsen, P. and Mouritsen, J. (2005). Disclosure of information on intellectual capital in Danish IPO Prospectuses. Accounting, Auditing \& Accountability Journal, Vol 18, No. 6, 713-732. http://dx.doi.org/10.1108/09513570510627685.

[6] Cazavan-Jeny, A. and Jeanjean, T. (2007). Levels of voluntary disclosure in IPO prospectuses: an empirical analysis. Review of Accounting and Finance, Vol. 6, No. 2, 131-149. http://dx.doi.org/10.1108/14757700710750810.

[7] Cordazzo, M. (2007). Intangibles and Italian IPO prospectuses: a disclosure analysis. Journal of Intellectual Capital, Vol. 8, No. 2, 288-305. http://dx.doi.org/10.1108/14691930710742853.

[8] Deeds, D. L., DeCarolis, D.M. and Coombs, J.E. (1997). The impact of firm-specific capabilities on the amount of capital raised in an initial public offering: Evidence from the biotechnology industry. Journal of Business Venturing, Vol. 12, 31-46. http://dx.doi.org/10.1016/S0883-9026(97)84970-1.

[9] Eirini, M. and Dimitris, T. (2014). Intellectual capital disclosure: the Greek case. International Journal of Learning and Intellectual Capital, Vol. 11, No. 1, 33-51. http://dx.doi.org/10.1504/IJLIC.2014.059226.

[10] Graham, J. R., Harvey, C. R.,Rajgopal, S. (2005). The economic implications of corporate financial reporting. Journal of Accounting $\begin{array}{llll}\text { and } & \text { Economics, } & \text { Vol. } & \text { 3-37. }\end{array}$ http://dx.doi.org/10.1016/j.jacceco.2005.01.002.

[11] Ho, H., Chau, K. and Cheung, P. (2012). Intellectual Capital Disclosure and Initial Public Offerings: Evidence from Hong Kong. Journal of Applied Economics and Business Research JAEBR, Vol. 2, No.2, 56-68.

[12] Ho, S.S.M. and Wong, K.S. (2001). A study of corporate disclosure practice and effectiveness in Hong Kong. Journal of International Financial Management and Accounting, Vol. 12, No. 1, 75-102. http://dx.doi.org/10.1111/1467-646X.00067.

[13] Ho, S.S.M. and Wong, K.S. (2001). A study of the relationship between corporate governance structures and the extent of voluntary disclosure. Journal of International Accounting, Auditing and Taxation, Vol. 10, No. 2, 139-56. http://dx.doi.org/10.1016/S10619518(01)00041-6.

[14] Hossain, M., Tan, L.M. and Adams M. (1994). Voluntary disclosure in an emerging capital market: some empiricak evidence from companies listed on the Kuala Lumpour stock exchange. The International Journal of Accounting, Vol. 29, No. 4, 334-351.

[15] Huang, C., Mike, T. and Luther, R.G. (2010). Contingency factors influencing the availability of internal intellectual capital information. Journal of Financial Reporting and Accounting, Vol. 8, No. 1, 4-21. http://dx.doi.org/10.1108/19852511011055916.

[16] Jaggi, B. (1997). Accuracy of Forecast Information Disclosed in the IPO Prospectuses of Hong Kong Companies. The International Journal of Accounting, Vol. 32, No. 3, 301-319. http://dx.doi.org/10.1016/S0020-7063(97)90013-3.

[17] Jensen, M. and Mekling, W. (1976). Theory of the firm: managerial behavior, agency costs and ownership structure. Journal of Finan- 
cial Economics, Vol. 3, No.4, 305-360. http://dx.doi.org/10.1016/0304-405X(76)90026-X.

[18] Jing Li, Pike, R. and Haniffa, R. (2008). Intellectual capital disclosure and corporate governance structure in UK firms. Accounting and Business Research, Vol. 38, No. 2, 137-159. http://dx.doi.org/10.1080/00014788.2008.9663326.

[19] Petersen, C., Plenborg, T. (2006). Voluntary disclosure and information asymmetry in Denmark. Journal of International Accounting, Auditing and Taxation 15, 127-149. http://dx.doi.org/10.1016/j.intaccaudtax.2006.08.004.

[20] Rimmel, G. and al (2009). Intellectual capital disclosures in Japanese IPO prospectuses. Journal of Human Resource Costing \& Accounting, Vol. 13, No. 4, 316-337. http://dx.doi.org/10.1108/14013381011010150.

[21] Singh, I.and Van der Zahn, M. (2008). Determinants of intellectual capital disclosure in prospectuses of initial public offerings. Accounting and Business Research, Vol. 38, No. 5, 409-431. http://dx.doi.org/10.1080/00014788.2008.9665774.

[22] Siti, M. T, and Jusop, M. (2011). Intellectual Capital Disclosure and Corporate Governance Structure: Evidence in Malaysia. International Journal of Business and Management, Vol. 6, No. 12, 109117.

[23] Striukova, L., Unerman, J. and Guthrie, J. (2008). Corporate Reporting of Intellectual Capital: Evidence from UK Companies. The British Accounting Review, 40: 297-313. http://dx.doi.org/10.1016/j.bar.2008.06.001.

[24] Verrechia. (1983). Discretionary disclosure. Journal of Accounting and economics, No. 5, 179-194. http://dx.doi.org/10.1016/0165$\underline{4101(83) 90011-3}$

\section{Working papers and communications}

[1] Baccouche, C. Errais, O. and Mzoughi, k. (2010). Les déterminant de la publication volontaire d'informations sociales: cas des entre prises tunisiennes. Manuscrit auteur, Capital immatériel : état des lieux et perspectives, Montpellier : France.

[2] Harman, K. (2013). Intellectual Capital Disclosure and the IPO Prospectus: An Exploratory. http://digitalcommons.liberty.edu/busi_fac_pubs.

[3] Kateb, I., Matoussi, H. and Bounfour, A. (2009). Les déterminants de l'offre volontaire d'information sur le capital immatériel : une analyse de contenu des rapports annuels des grandes firmes françaises. Manuscrit auteur, La place de la dimension européenne dans la Comptabilité Contrôle Audit, Strasbourg : France. 